\title{
Effect of synergized filler as protein base substitution and replacer on technological properties of low-fat spreadable processed cheese analogue
}

\begin{abstract}
Milk protein concentrate in Low-Fat Spreadable processed cheese analogue replaced and substituted with synergized filler branded as "Gervizol" which containing soy proteins, soy fibers, maltodextrine and modified starch. Cheese trails which substitute milk protein concentrate with 0 (control), $1\left(\mathrm{~T}_{1}\right), 2\left(\mathrm{~T}_{2}\right)$ and $3 \%\left(\mathrm{~T}_{3}\right)$ from synergized filler were prepared. All treatments were analyzed toward microbial, physico-chemical, sensorial and textural characteristics during six months of storage. The obtained chemical results revealed that all treatments $\mathrm{pH}$ values were higher than control in the beginning and end of storage. Moisture contents were higher than control in the beginning and end of storage. On the other hand, treatment 2 retained highest moisture contents comparing with rest of treatments. All treatments fat, salt and protein\% were slightly increased in end of storage compared with fresh cheese. Microbiologically, total counts were generally low. Molds and yeasts, coliforms and anaerobic sporeformers were not detected during storage Trail treatments adhesiveness indicates lowering values $(\mathrm{g} / \mathrm{sec})$ comparing with control treatment in the beginning and end of storage period. The linear increase of the synergist replacer used content had effect on decrease of chewiness. The synergized replacer used decreased the cohesiveness during storage period for treatment 1 and 2 . While treatment 3 was similar with control which is increased during storage period. Also, gumminess and hardness values were decreased for all treatments including control. Treatment(3) retained highest resilience at end of storage period. Treatments springiness decreased due to the increase in the synergist substitute and replacer used. Sensory evaluation showed that $T_{2}$ had significantly higher flavor, spreadability and color .Cost saving of treatments were $4.919,3.279$ and $1.639 \%$ for $\mathrm{T}_{3}, \mathrm{~T}_{2}$ and $\mathrm{T}_{1}$ respectively
\end{abstract}

Keywords: synergized filler, processed cheese, cheese analogue, textural analysis, cost saving

\author{
Volume 2 Issue 5 - 2015
}

\author{
Tareq Alnemr,' Ahmed Basioni,'2 \\ AmalHassan,' Mahmoud Alghanam' \\ 'Department of Dairy Science and Technology, Alexandria \\ University, Egypt \\ ${ }^{2}$ Department of processed cheese, Labanitta factory, Egypt
}

Correspondence: Tareq Alnemr, Department of Dairy Science and Technology, Faculty of Agriculture, Alexandria University, El-shatby, Alexandria, Egypt, Tel +20 I00 393 5325, Email tareqalnemr1962@gmail.com

Received: March 24, 2015 | Published: September 28, 2015

\section{Introduction}

Attempts to reduce cheese costs have led to the development of imitation cheeses based on casein and its derivatives and the use of vegetable fat to replace the more costly milk fat. ${ }^{1}$ Due to the high cost and certain functionality limitations of casein, a number of researchers have investigated lower cost vegetable proteins as casein substitutes, such as peanut, ${ }^{2}$ cottonseed and soy protein isolates, ${ }^{3}$ but these have had limited success.

Different procedures for cheese analogues with less or no protein are described. Zwiercan et al. ${ }^{1}$ prepared cheese analogues from pregelatinized or modified high-amylose starch in partial replacement of caseinate. Mounsey \& O'Riordan ${ }^{4}$ manufactured imitation cheese with various levels of pre-gelatinised maize starch. Meltability decreased with increasing levels of starch. A mixture of sodium caseinate, soy protein isolates and corn starch has been used to prepare imitation cheese. ${ }^{5}$ Other manufacturers of imitation cheese have used modified starches or soy isolates and gelatin as caseinate replacement. ${ }^{6}$ Starches significantly reduced compared to the control with potato starch having the greatest effect. Rice starch appears to have the most potential as a partial casein substitute in imitation cheese. ${ }^{7}$ The effect of starch on the properties of the processed cheeses was attributed to phase behaviors between the protein and the starch, which was shown in confocal laser scanning micrographs. ${ }^{8}$
The objective of this investigation is to evaluate the textural characteristics and sensory acceptability of processed cheeses manufactured with as a synergism system of replacers and substitutes mixture which containing (soy protein and fibers, maltodextrine and modified starches) branded with "Gervizol" as milk protein replacer and substitutes, hence the low cost product is also targeted. The textural attributes of the produced cheeses were analyzed by instrumental techniques and sensory panels and the interrelationships among the instrumental, sensory, and composition attributes were examined utilizing Pearson product moment correlations.

\section{Materials and methods}

\section{Materials}

Cream Cheese which containing dry matter $48.5 \%$; moisture $51.5 \%$; total protein $8.8 \%$ and $\mathrm{pH} 4.75$ imported from New Zealand (Fonterra, Auckland). Low heat skimmed milk powder $(33.4 \%$ protein) obtained from (Dairy America, California), USA Milk protein concentrate (MPC70\%) obtained from (Dairy America, California), USA Emulsifying salts used (Ladenburg, W, Germany) were a mixture of JOHA-S4 (consists of poly and diphosphates E452, E450, P2O5 61.5\% $\pm 1, \mathrm{pH} 7.5 \pm 0.3$ ) and JOHA-S9s (consists of poly and diphosphates E452, E450, P2O5 58.4\% $\pm 1, \mathrm{pH} 9 \pm 0.3$ ) with a ratio of 1:1. NisinE234 2.5\% obtained from, Danisco A/S, DK-7200 
Grindsted. Denmark. Potassium sorbate was obtained from Hangzhou Ruijiang Chemical Company., Ltd. Hangzhou, Zhejiang, China. Lactosan matured cheddar cheese powder type 130222 and mild blue cheese powder type 150203 obtained from Lactosan A/S Nordbakken, Denmark. Gervisol 218 as a mixture of soy fibers, soy proteins, maltodextrine, polydextrose and modified starches (protein 18\%; functional polysaccharide $68 \%$ Dietary fiber $2.5 \%$; Fat $0.4 \%$; Ash $3 \%$ and Moisture 7-9\%) obtained from AWA co. for food additives, Egypt.

\section{Methods}

The control and different blends of processed cheese trails were prepared and manufactured at AL Mansour Company, for Trade and Distribution (Seclam). Brand name (labanita) Alexandria, Egypt, using a batch cooker Karl Schnell Type (046/FV 175/100) with a capacity of 100kg (Karl Schnell Company, Germany). Processing was carried out at a temperature of $90^{\circ} \mathrm{C}$ for 4 minutes" according to Kosikowski, (1978). SABAL ML4-1 machine was used for packaging of cheese.

Chemical analysis including Dry matter; fat; $\mathrm{pH}$; total protein; salt; according to AOAC. ${ }^{9,10}$ On the other hand, Texture Analyzer TA.XT plus (Stable Micro Systems, Surrey, UK) using P/0.5S 1/2 inch diameter ballprobe Max recommended load: $50 \mathrm{~kg}$ Manu Material: Stainless Steel Max Operating Temp: 200C (Pre-Test Speed 1.5mm/s. Test Speed $2.0 \mathrm{~mm} / \mathrm{s}$. Post-Test Speed $10.0 \mathrm{~mm} / \mathrm{s}$. Distance $5 \mathrm{~mm}$ ). Hardness, Resilience, adhesiveness, springiness, cohesiveness, gumminess and chewiness were calculated as described by Bourne. ${ }^{11}$ Analyses were carried out three times and the mean of data was calculated. The characteristics of the device texture profile analysis (TPA). Sensory evaluation was carried out by a panel consisting of 10-20 cheese graders, including staff members and assistants at the University of Alexandria, Faculty of Agriculture and specialists in the field of dairy and non-specialist people and people of different ages and alliteration. The sensory evaluation procedure was modified from the method described by Ayad et al. ${ }^{12}$ The averages of sensory evaluations data with standard deviations were determined. All Microbiological counts were determined as described in Difco's Manual. ${ }^{13}$

\section{Experimental design}

Processed cheese formulation planned according to the Egyptian standards for processed cheese spreads. ${ }^{14}$ All cheese trials were made using 18\% Cream Cheese, milk protein concentrate: control 14\%, Trail $\mathrm{T}_{1} 13 \%, \mathrm{~T}_{2} 12 \%$ and $\mathrm{T}_{3} 11 \%$. 4\% skim milk powder, $0.8 \%$ Lactosan Cheese Powder (Type130222), 0.8\%Lactosan Cheese Powder (Type 150203), 1\% emulsifying salts S4, 1\% emulsifying saltsS9, $1 \%$ edible sodium chloride, $0.38 \%$ citric acid, $0.4 \%$ Palsgaard ${ }^{\circledR} 5815$ stabilizers, $0.02 \%$ Nisaplin (Nisin 2.5\%-E234), $0.1 \%$ Potassium sorbate and water $60.5 \%$ added. Milk protein concentrate has substituted by Gervisol $\%$ zero for control trail, $1 \%$ for $\mathrm{T}_{1}, 2 \%$ for $\mathrm{T}_{2}, 3 \%$ for $\mathrm{T}_{3}$.

\section{Results and discussion}

Data presented in Table 1 illustrate the chemical analysis of processed cheese made with different substitution levels of milk protein replacer. The moisture content of all treatments slightly increased throughout the level of replacement. This would possibly result from the replacer water binding. However, the moisture content of all processed cheese was within the legal limits according to Egyptian standard..$^{14}$ All the imitated cheese had lower dry matter and protein content than the control.
$\mathrm{pH}$ results of processed cheese trails made with different substitution levels of milk protein replacer during storage period were presented in Figure 1. Generally $\mathrm{pH}$ of all treatments values (Figure 1) was higher than control in the beginning and end of storage. At $\mathrm{pH}$ values and dry matter content enables comparing the effect of different concentrations of milk protein replacer used because both $\mathrm{pH}$ and dry matter influence the consistency of processed cheeses. ${ }^{15-17}$ All treatments moisture contents were higher than control in the beginning and end of storage. On the other hand treatment 2 retained highest moisture contents comparing with the rest of treatments; this may be due to the hydrophilic nature of these proteins Rani \& Verma. ${ }^{18}$

\section{$\mathrm{pH}$ during storage period}

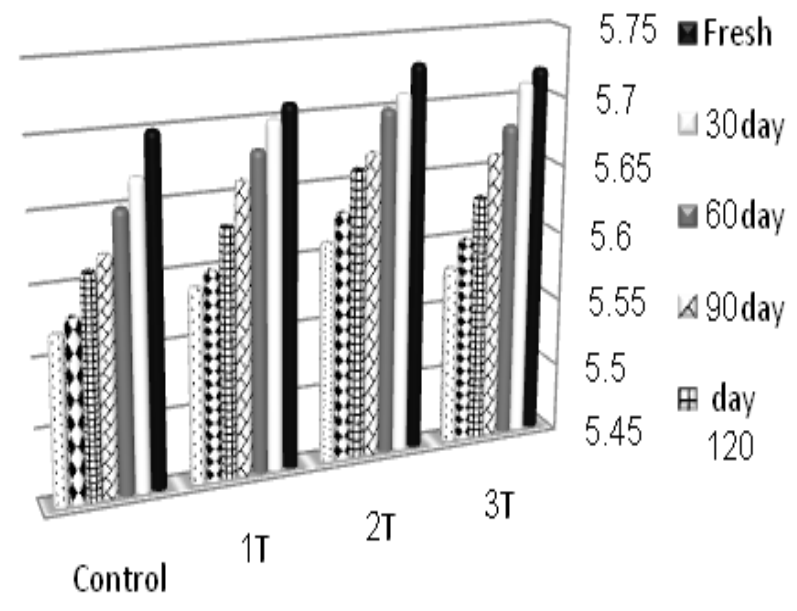

Figure I pH of low-fat spreadable processed cheese analogue replaced and substituted with synergized filler mixture during storage period.

Chemical analysis results of processed cheese trails made with different substitution levels of milk protein replacer during storage period were presented in Figure 2. The moisture content of all treatments slightly increased throughout the level of replacement. All treatments moisture contents were higher than control in the beginning and end of storage. On the other hand treatment 2 retained highest moisture contents comparing with the rest of treatments. This would possibly result from the replacer water binding. However, the moisture content of all processed cheese was within the legal limits. The chemical composition of all treatments was in accepted range according to Egyptian standard. ${ }^{14}$ These results agreed with those reported by O'Malley et al., ${ }^{19}$ who found that pilot-scale imitation cheeses had higher moisture and lower levels of protein than the commercial ones.

Content of all treatments fat $\%$ was slightly increased at the end of storage period comparing with fresh cheese as a result of moisture decreasing. Protein content slightly increased (all treatments) at the end of storage compared with fresh cheese as a result of moisture decreasing. These results agreed with those reported by Salem et al., ${ }^{20}$ Kebray et al..$^{21,22}$ Protein and salt content slightly increased in all treatments at the end of storage compared with fresh cheese as a result of moisture decreasing. Several researches results reported that the protein contents of processed cheese spread were increased with increasing the ratio of protein source fortifications. ${ }^{23}$

Total bacterial count, molds, yeast and anaerobic spore former in formulated processed cheese. Total bacterial count slightly changed 
among treatments. It was ranged from $1.0 \times 10^{3}$ to $1.2 \times 10^{3}$. Total count was gradually increased with the progress of storage period (Figure 3 ). In general, total count was triplicated (from $1.0 * 10^{3}-3.1 * 10^{3}$ ) by the end of storage period. The specified microorganisms (molds, yeast, and anaerobic spore former) were not detected in all cheese treatments. This low bacterial count and the absence of molds and yeast and spore former can be attributed to the controlled hygienic condition and also to heat treatment. ${ }^{24}$ This low microbial content can be characterized the formulated cheese as good microbiological quality processed cheese. These results are in accordance with Muir et al., ${ }^{25}$ Nour El-Diam et al., ${ }^{26}$ reported slightly higher values of aerobic plate count $\left(<1-4.56 \log _{10} \mathrm{cfu} / \mathrm{gm}\right)$ and total coliform bacteria $(<3-$ $30 \mathrm{MPN} / \mathrm{gm}$ ) than those reported in the present study.

Table I Chemical analysis of low-fat spreadable processed cheese replaced and substituted with synergized filler mixture

\begin{tabular}{lllll}
\hline Treatment & \%Control & $\% \mathbf{T}_{1}$ & $\% \mathbf{T}_{2}$ & $\% \mathbf{T}_{3}$ \\
\hline $\mathrm{pH}$ & $5.70 \pm 0.05$ & $5.72 \pm 0.04$ & $5.73 \pm 0.02$ & $5.7 \mathrm{I} \pm 0.06$ \\
Moisture\% & $69.00 \pm 1.00$ & $69.40 \pm 0.50$ & $70.10 \pm 0.20$ & $69.20 \pm 0.70$ \\
Fat\% & $7.00 \pm 0.10$ & $7.00 \pm 0.10$ & $7.00 \pm 0.40$ & $7.00 \pm 0.30$ \\
Total protein\% & $12.80 \pm 0.50$ & $12.10 \pm 0.70$ & $11.40 \pm 0.60$ & $10.70 \pm 0.40$ \\
Fat/DM\% & 22.58 & 22.87 & 23.74 & 23.49 \\
Protein / DM\% & 41.29 & 39.54 & 38.12 & 35.9 \\
Salt \% & $0.60 \pm 0.10$ & $0.63 \pm 0.20$ & $0.7 \pm 0.30$ & $0.68 \pm 0.20$
\end{tabular}

Data are means $\pm S D ; n=3$

Moisture \% during storage period
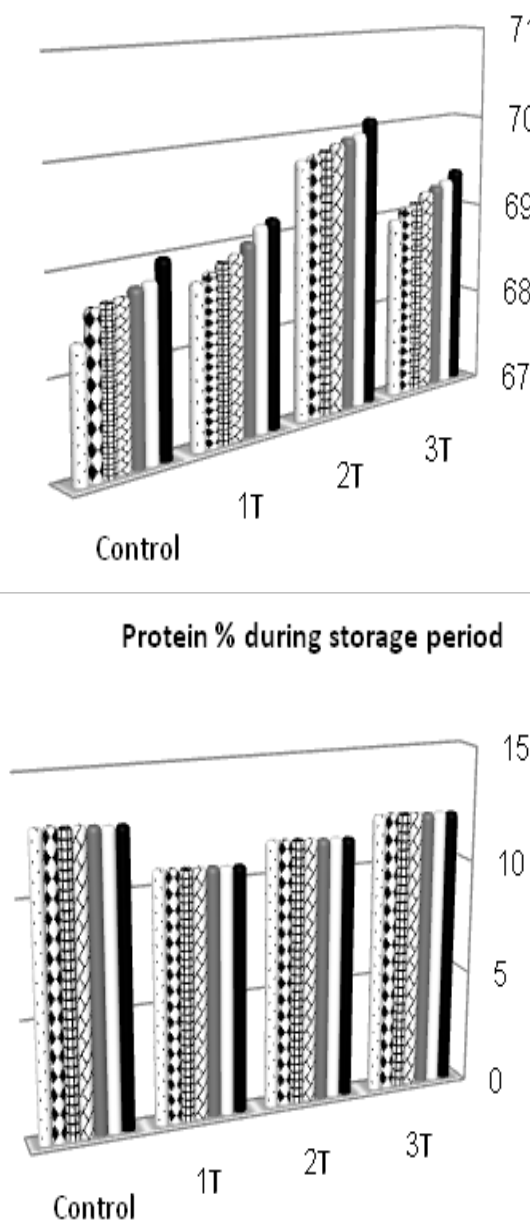

Fat $\%$ during storage period

Protein \% during storage period

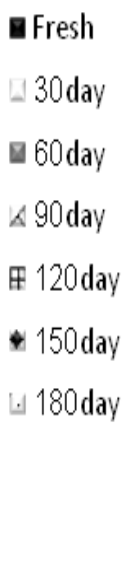

15

$$
\begin{aligned}
& \text { Dresh } \\
& \square 30 \text { day } \\
& \square 60 \text { day } \\
& \triangle 90 \text { day } \\
& +120 \text { day } \\
& \square 150 \text { day } \\
& 4180 \text { day }
\end{aligned}
$$

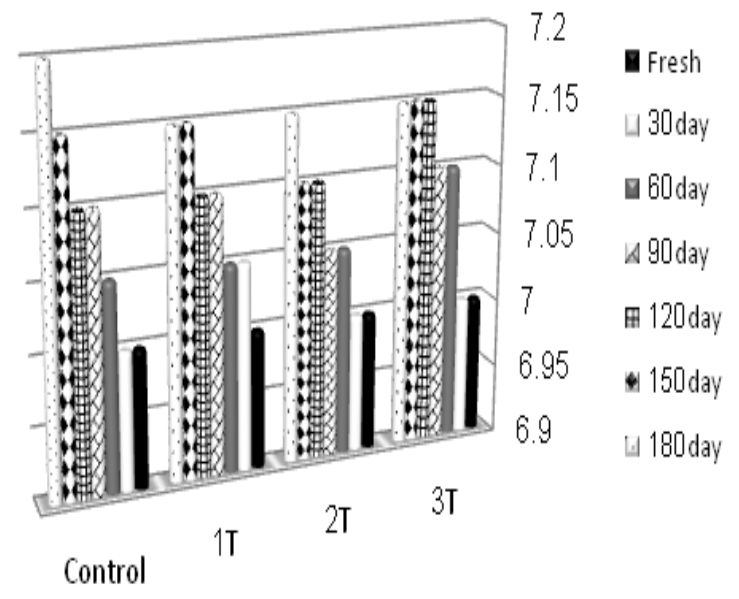

Salt $\%$ during storage period

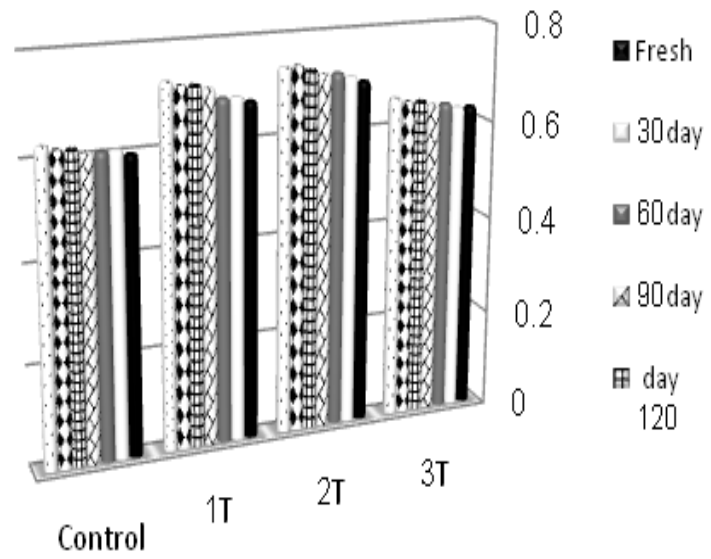

Figure 2 Chemical analysis of low-fat spreadable processed cheese analogue replaced and substituted with synergized filler mixture during storage period (Average of three replicates). 


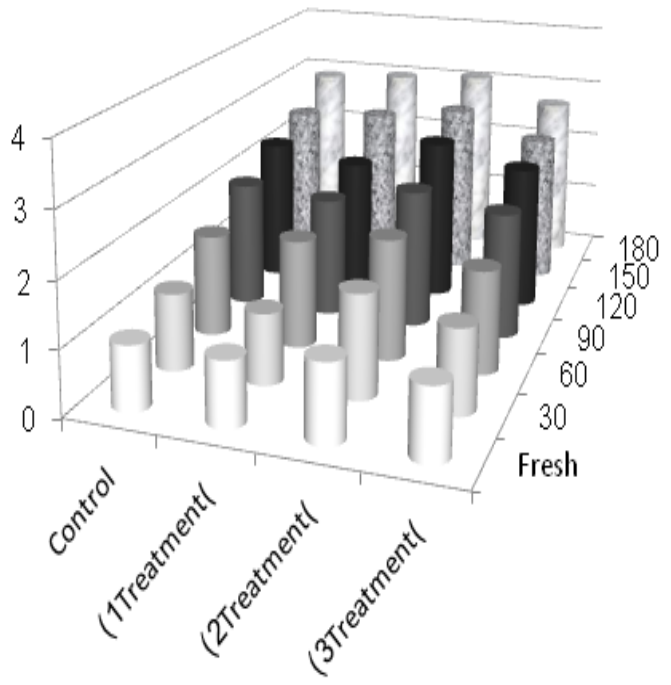

Fresh $\square 30 \quad \square 0 \quad \square 0 \square 120 \square 150 \square 180$

Figure 3 Microbial count of low-fat spreadable processed cheese replaced and substituted with synergized filler mixture during storage period (Average of three replicates).

Data presented in Figure 4 for textural analysis and Figure 5 for textural appearance showed that trail $\mathrm{T}_{2}$ and $\mathrm{T}_{3}$ had the lower values of adhesiveness that the higher ratio of Gervisol in the cheese blend led to firmer product. Adhesiveness values of $\mathrm{T}_{2}$ were lower than control, $\mathrm{T}_{1}$ and $\mathrm{T}_{3}$ in the beginning and end of storage. The results of processed cheese adhesiveness which indicates lowering values $(\mathrm{g} / \mathrm{sec})$ comparing with control treatment in the beginning and end of storage period. It has been seemed that the synergist substitute and replacer used decreased adhesiveness. Many research results explained the factors affected adhesiveness in processed cheese; a higher fat content resulted in softer, less adhesive cheese analogues. ${ }^{27} \mathrm{Chen}$ et al. ${ }^{2}$ who reported that increasing oil content augmented firmness and decreased adhesiveness and of processed cheese analogues. Similar result was observed by Bryant et al., ${ }^{28}$ Koca \& Metin, ${ }^{29}$ that decrease in fat content leads to a significant $(\mathrm{p}<0.05)$ decline of the adhesiveness of Cheddar and fresh Kashar cheeses. Increase in the xanthan gum concentration lowered the adhesiveness values of reduced fat Cheddar cheeses. ${ }^{30,31}$ In contrast, there was an increase in the adhesiveness of processed cheeses when cheddar was replaced by casein. ${ }^{32}$

Treatment $\left(\mathrm{T}_{1}\right)$ Chewiness values were higher than control, $\mathrm{T}_{2}$ and $\mathrm{T}_{3}$ in 30days of storage and $\mathrm{T}_{3}$ higher than control, $\mathrm{T}_{1}$ and $\mathrm{T}_{2}$ in end of storage.This data confirm the figures obtained from the measurement of adhesiveness. The linear increase of the synergist substitute and replacer used content had effect on decrease of chewiness. Zalazar et $a .^{33}$ reported that by decreasing the fat content, the protein matrix became more compact and the cheese texture was chewier. The use of fat replacers decreased the chewiness characteristics by loose the compact and dense protein matrix characteristics. ${ }^{29,34}$ Koca \& Metin $^{29}$ found out that the low-fat fresh Kashar cheeses produced by using fat replacers (SimplessesD- 100 and Raftiline ${ }^{\circledR} \mathrm{HP}$ ) were softer and less chewy. This result could be explained by activity of polar groups in fat mimetics resulting in increase in cheese moisture content and consequently improving the low-fat cheese texture. Konuklar et al..$^{35}$ also reported that the low fat cheese samples exhibited more chewiness as the moisture contents decreased and vice versa.
Data revealed that the control sample which got the highest value of cohesiveness, while $T_{1}$ and $T_{2}$ had the lowest one. $T_{3}$ had high cohesiveness value of cohesiveness value due to the high level of protein substitution by soy protein and replaced with starch which reduced the solidity of cheese. The reduction in the cohesiveness of imitation cheese by starch was due to reduction in the protein content and possibly by stress localization at the starch -protein matrix interface. Results of Mounsey ${ }^{36}$ are indicative that the starch functioned as filler allowing the casein to dominate the products textural properties. The results of Awad et al., ${ }^{37}$ indicated that the cohesiveness of cheese samples decreased as lupine paste ratio increased in the blend. After 90days of storage, the cohesiveness value greatly increased in all cheese, and control treatment showed the highest value.

Treatment $\left(\mathrm{T}_{1}\right)$ Gumminess were higher than control, treatment $\left(\mathrm{T}_{2}\right)$ and treatment $\left(\mathrm{T}_{3}\right)$ in 30days storage and treatment $\left(\mathrm{T}_{2}\right)$ higher than control, treatment $\left(\mathrm{T}_{1}\right)$ and treatment $\left(\mathrm{T}_{3}\right)$ in end of storage. This finding corroborates the ideas of Koca \& Metin $^{29}$ which revealed that the use of fat replacers decreased the gumminess values in Kashar cheese. In contrast, Awad et al. ${ }^{37}$ reported that Gumminess showed the maximum values in fresh processed cheese analogue with $50 \%$ lupine and in the stored cheese with $75 \%$ lupine. Gumminess values increased during storage of all treatments including control with storage. These data agree with the results of El-Baz et al. ${ }^{38}$

\section{Adhesiveness(g/sec)}

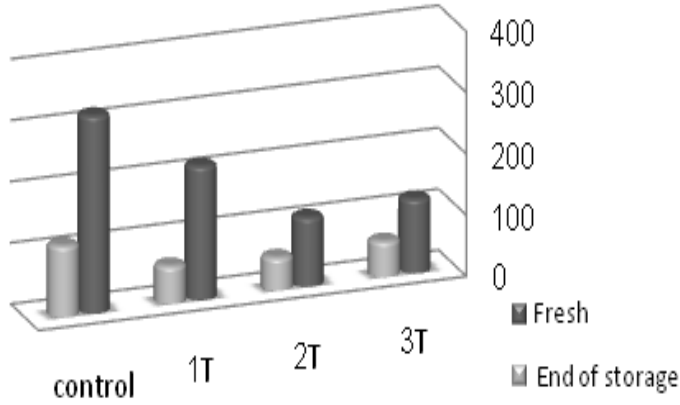

Figure 4a Textural analysis of low-fat spreadable processed cheese replaced and substituted with synergized filler mixture during storage period.

The synergist substitute and replacer used decreased the Hardness during storage period for control and $T_{3}$. While $T_{1}$ was similar with $\mathrm{T}_{2}$ which is increased during storage period. On the other hand $\mathrm{T}_{2}$ had the highest value of hardness while the control sample had the lowest one. $\mathrm{T}_{3}$ tend to be less solid because of the increased ratio of protein substitution with Gervisol. Hardness of all treatments were higher than control treatment during storage period. Treatment $\mathrm{T}_{2}$ retained highest hardness at end of storage period. That attributed this phenomenon to binding water through the synergist substitute and replacer used; some findings are consistent with the results obtained. Mounsey \& O'riordan, ${ }^{4,7}$ Mounsey, ${ }^{36}$ Pınar \& Mustafa ${ }^{39}$ reported that hardness was increased by wheat, potato or maize starch but reduced by waxy-maize or rice starch. Rice starch appears to have the most potential as a partial casein substitute in imitation cheese. Silva et al ${ }^{40}$ also found a direct correlation between sensorial consistency and measures of hardness in the sensory characterization of processed cheeses with different fat and water contents. In contrast Koca \& Metin ${ }^{29}$ studied the textural, melting and sensory properties 
of Turkish traditional processed cheese, known as Kashar cheese which was produced by one of carbohydrate-based fat replacer namely, $5.0 \% \mathrm{w} / \mathrm{w}$ Raftiline ${ }^{8 H P}$ with another two protein-based fat replacer $\left(1.0 \% \mathrm{w} / \mathrm{w}\right.$ Simplesse ${ }^{\circledR D}-100$ and $1.0 \% \mathrm{w} / \mathrm{w}$ Dairy-Lo $\left.{ }^{\mathrm{TM}}\right)$. The result was being compared with the control samples of low-fat cheese without fat replacer and the full-fat cheese. In addition, the hardness of imitation cheese increased linearly with the concentration of added starch. ${ }^{41}$ The addition of starch affected the microstructure of imitation cheese as the interactions between casein and starch resulted in the mutual exclusion of each component. ${ }^{41}$ The addition of starch increased the firmness of a model processed cheese, and the degree of increase depended on the type and the concentration of starch added. Because starch addition has the ability to increase the firmness of the cheese, a reduction in the concentration of protein could be offset by a small addition of starch without drastically affecting the rheological properties of the processed cheese.$^{42}$ Montesinos-Herrero et al. ${ }^{41}$ found that the addition of fiber in imitation cheese to increase the viscous modulus which explains the increased hardness of Processed Cheese

\section{Chewiness(g-mm)}

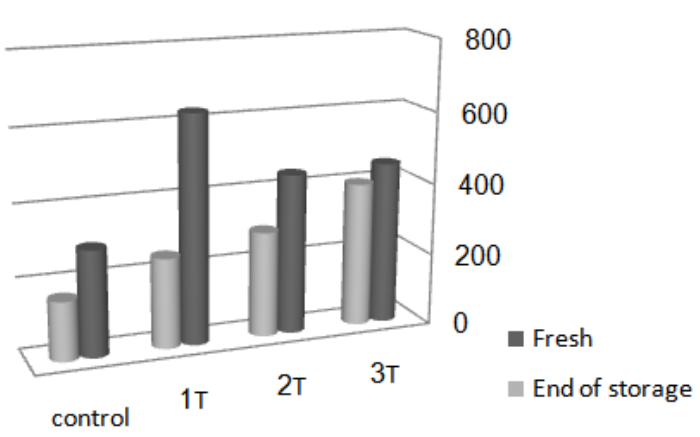

Gumminess(g/sec)

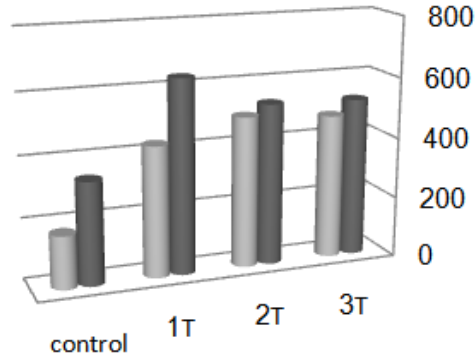

Hardness(g)

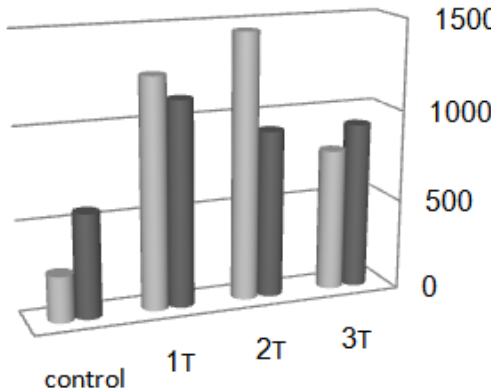

Cohesiveness(ratio)

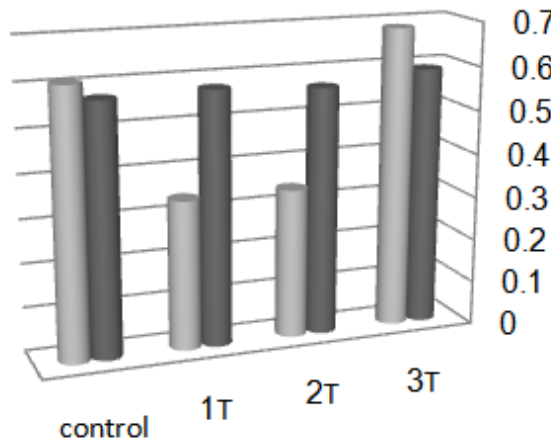

Resilience(ratio)

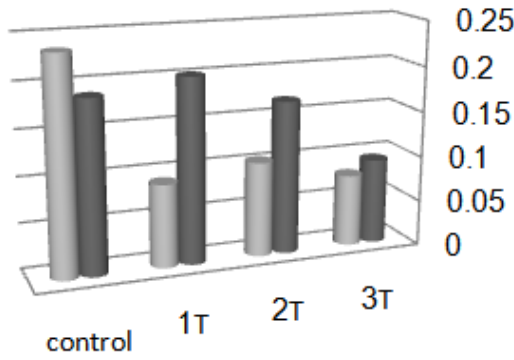

Springiness(mm)

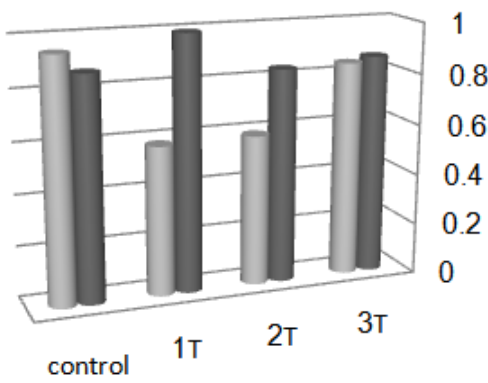

Fresh

End of storage

- Fresh

End of storage
- Fresh

End of storage

Figure 4 Textural analysis of low-fat spreadable processed cheese replaced and substituted with synergized filler mixture during storage period.

Control retained the highest values of springiness comparing with treatment $T_{1}, T_{2}$ and $T_{3}$ during storage period. Generally springiness decreased due to the increase in the synergist substitute and replacer used. Resilience of all treatments was higher than control during storage period. Treatment $\left(\mathrm{T}_{3}\right)$ retained highest resilience at end of storage period. Cost varies between different treatments depending on the ingredients involved in each treatment and the price of each component and the addition ratio of each component with the transaction. Treatment samples according the prices regarding 2013 saved $1.639 ; 3.279$ and $4.919 \%$ for $\mathrm{T}_{1 ;} \mathrm{T}_{2}$ and $\mathrm{T}_{3}$ respectively. On the other hand; organoleptic properties (Table 2) with companions of means using Duncan multiple range test showed that flavor in treatment $\left(\mathrm{T}_{2}\right)$ had the highest value whereas treatment $\left(\mathrm{T}_{3}\right)$ gave the lowest evaluation value. For texture highest evaluation value was for treatment $\left(\mathrm{T}_{3}\right)$ while the lowest value was for control. With regard to section grade, treatment (1) gave significantly higher value than control and treatment $\left(\mathrm{T}_{2}\right)$ whereas it was statically similar to treatment $\left(\mathrm{T}_{3}\right)$. For section industry treatment $\left(\mathrm{T}_{2}\right)$ and $\left(\mathrm{T}_{3}\right)$ gave significantly higher value than control, whereas treatment $\left(T_{1}\right)$ was of intermediate value. For colure the highest value was for treatment 
$\left(T_{2}\right)$ and $\left(T_{3}\right)$ and the lowest value was for control. Treatment $\left(T_{2}\right)$ had

gave the highest score for treatment $\mathrm{T}_{2}(94.1 \%)$ and the lowest score significantly higher flavor. Comprehensive evaluation of treatments

for control treatment $(73.3 \%)$.

Table 2 Sensory evaluation of low-fat spreadable processed cheese replaced and substituted with synergized filler mixture during storage period

\begin{tabular}{|c|c|c|c|c|c|c|c|c|c|}
\hline Treatment & Flavor & & Texture & & Section & & Color & & $\begin{array}{l}\text { Overall } \\
\text { grade }\end{array}$ \\
\hline & Grade* & $\begin{array}{l}\text { Description } \\
\text { (intensity) }\end{array}$ & Grade** & $\begin{array}{l}\text { Description } \\
\text { (intensity) }\end{array}$ & Grade* & $\begin{array}{l}\text { Description } \\
\text { (intensity) }\end{array}$ & Grade* & $\begin{array}{l}\text { Description } \\
\text { (intensity) }\end{array}$ & -100 \\
\hline Control & 3.4 & $\begin{array}{l}\text { 3.15 Cheddar } \\
\text { cheese -like }\end{array}$ & 3.15 & 3.2500a Spreadable & 3.4 & 3.35 Closed & 3.7 & 3.75 Regular & $73.30 \%$ \\
\hline Treatment (I) & 3.4 & 3.2 Creamy & 3.2 & 3.3000a Spreadable & 3.7 & 3.6 Closed & 3.75 & 3.85 Regular & $86.40 \%$ \\
\hline Treatment (2) & 3.5 & 3.45 Creamy & 3.3 & 3.4000a Spreadable & 3.25 & 3.7 Closed & 3.9 & 3.9 Regular & $94.10 \%$ \\
\hline Treatment (3) & 3.25 & 3.I Creamy & 3.4 & 3.4500a Spreadable & 3.5 & 3.7 Closed & 3.9 & 3.9 Regular & $90.30 \%$ \\
\hline
\end{tabular}

*, Grade (I-4), I, bad, 2, sufficient, 3, good, 4, very good

**, grade (I-4), on scale from (I-4), I, pasty, 2, soft, 3, normal, 4, firm

Means followed by the same letter(s) are insignificantly different according Duncan's multiple range tests
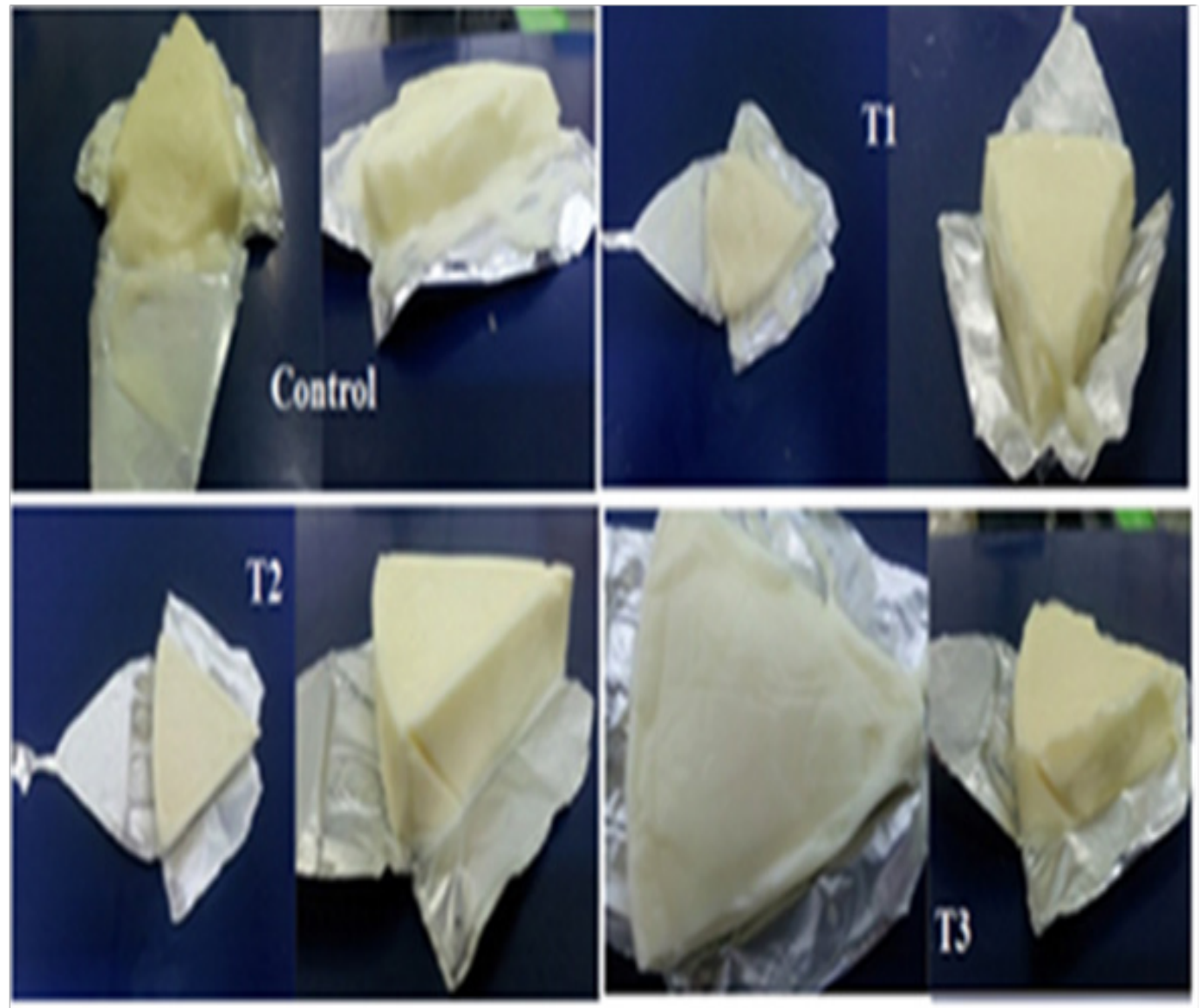

Figure 5 Appearance of low-fat spreadable processed cheese replaced and substituted with synergized filler mixture during storage period.

\section{Acknowledgements}

None.

\section{Conflict of interest}

Author declares that there is no conflict of interest. 


\section{References}

1. Zwiercan GA, Lacrourse NL, Lenchin JM. Imitation cheese products containing high amylose starch as total caseinate replacement. National Starch and Chemical Corp. 1987.

2. Chen SL, Wan PJ, Lucas EW, et al. Utilization of peanut protein and oil in cheese analogs. Food Technol. 1979;33(7):88-93.

3. Taranto MV, Yang CST. Morphological and textural characterisation of soybean Mozzarella cheese analogs. Scan Elect Microsc. $1981 ; 3: 483-492$

4. Mounsey JS, O'Riordan ED. Empirical and Dynamic Rheological Data Correlation to Characterize Melt Characteristics of Imitation Cheese. Journal of Food Science Volume. 1999;64(4):701-703.

5. Lee $\mathrm{CH}$, Son HS. The textural properties of imitation cheese by response surface analysis. Korean Journal of Food Science \& Technology 1985;17(5):361-370.

6. Kiely LJ, McConnell SL, Kindstedt PS. Observations on the melting behavior of imitation Mozzarella cheese. J Dairy Sci 1991;74(10):3568-3572.

7. Mounsey JS, O'Riordan ED. Characteristics of imitation cheese containing native starches. Journal of food science. 2001;66(4):586-591.

8. Aiqian YE, Sheelagh Hewitt, Steve Taylor. Characteristics of rennet-casein-based model processed cheese containing maize starch: Rheological properties, meltabilities and microstructures. Food Hydrocolloids. 2009;23(4):1220-1227.

9. AOAC. Official Methods of Analysis, Moisture content, Method 926.08. Arlington, VA, USA; 2000

10. AOAC. Official Methods of Analysis, Total protein, Method 920.123. Arlington, VA, USA; 2000.

11. Bourne MC. Texture profile analysis. Food Technology. 1978;62-72 p.

12. Ayad EHE, Darwish SM, Abu-Elreesh SMI. The quality of market milk and some dairy productus collected from Alexandria City. Egyptian $J$ Dairy Sci. 2009;37(2):139-159.

13. Difco's Manual. Dehydrated culture Media and Reagents for Microbiology. 10th ed. USA: Difco laboratories lnc; 1985.

14. Egyptian standard organization. Guidelines of Milk and Milk Products Quality. 2010.

15. Francolino S, Locci F, Ghiglietti R, et al. Use of milk protein concentrate to standardize milk composition in Italian citric Mozzarella cheese making. LWT- Food Science and Technology. 2010;43(2):310-314.

16. Marchesseau S, Gastaldi E, Lagaude A, et al. Influence of $\mathrm{pH}$ on protein interactions and microstructure of process cheese. Journal of Dairy Science. 1997;80(5):1483-1489.

17. Lee SK, Anema S, Klostermeyer H. The influence of moisture content on the rheological properties of processed cheese spreads. Int J Food Sci Technol. 2004;39(7):763-771.

18. Rani M, Verma NS. Changes in organoleptic quality during ripening of cheese made from cows and soya milk blends, using microbial rennet. Food Chemistry. 1995;54(4):369-375.

19. O’Malley AM, Mullivihill DM, Singh TK. Proteolysis in rennet casein-based cheese analogues. Int Dairy J. 2000;10(11):743-753.

20. Saleem RM. Manufacture of processed cheese from uncommon sources Zanco J. 1987;5:4

21. Kebary KMK, Hussein SA, Badawi RM. Impact of fat replacer on the properties of low fat processed cheese spread. Proceedings of the 7th Egyptian Conference for Dairy Science and Technology. 1998. p. 383-401.
22. Kebary KMK, Hussein SA, Badawi RM. The use of whey proteins in flavoured low fat processed cheese spread. Proceedings of the 8th Egyptian Conference for Dairy Science and Technology. 2001. p. 369-381.

23. Verma SK, Upadhyay S, Chandra R, et al. Preparation of processed cheese spread using tofu, mozzarella and cheddar cheese. International Journal of Food and Nutritional Sciences. 2013;2(2):19-22.

24. Kung H, Tsai Y, Hwang C, et al. Hygienic quality and incidence of histamine-forming Lactobacillus species in natural and processed cheese in Taiwan. J Food Drug Anal. 2005;13(1):51-56.

25. Muir DD, Tamime AY, Shenana ME, et al. Processed cheese analogue incorporating fat-substitutes. 1. Composition, microbiological quality and flavour changes during storage at $5^{\circ} \mathrm{C}$. LWT-Food Science and Technology. 1999;32(1):41-49.

26. Nour El-Diam MSA, IEM El-Zubeir. Comparison of microbiological quality of processed and non-processed Sudanese white cheese. Res $J$ Microbiol. 2006;1(3):273-279.

27. Stampanoni CR, Noble AC. The influence of fat, acid, and salt on the temporal perception of firmness, saltiness and sourness of cheese analogs. Journal of Texture Studies. 1991;22(4):381-392.

28. Bryant A, Ustunol Z, Steffe J. Texture of Cheddar cheese as influenced by fat reduction. J Food Sci. 1995;60(6):1216-1221.

29. Koca N, Metin M. Textural, melting and sensory properties of low-fat fresh Kashar cheeses produced by using fat replacers. Int Dairy J. 2004; 14(4):365-373.

30. Nateghi L, Shahin Roohinejad, Alfonso Totosaus, et al. Optimization of textural properties and formulation of reduced fat Cheddar cheeses containing fat replacers. Journal of Food, Agriculture \& Environment. 2012;10(2):46-54

31. Nair MG, Mistry VV, Oommen BS. Yield and functionality of Cheddar cheese as influenced by homogenization of cream. International Dairy Journal. 2000;10(9):647-657.

32. El-Nemr TM. Chemical, Reheological and organoleptic properties of processed cheese analogs (partial and whole replacement of cheese). $J$ Adv Agric Res (Fac Agric SabaBasha Alexandria). 2006;11(4):699-710.

33. Zalazar CA, Zalazar CS, Bernal S, et al. Effect of moisture level and fat replacer on physicochemical, rheological and sensory properties of low fat soft cheeses. Int Dairy J. 2002;12(1):45-50.

34. Lobato-Calleros C, Aguirre-Mandujano E. Viscoelastic properties of white fresh cheese filled with sodium caseinate. J Texture Stu. 2000;31(4):37-390.

35. Konuklar G, Inglett GE, Warner K, et al. Use of a $\beta$-glucan-glucan hydro colloidal suspension in the manufacture of low-fat Cheddar cheeses: Textural properties by instrumental methods and sensory panels. Food Hydrocolloid. 2004;18(4):535-545.

36. Mounsey JS. Effect of wheat starch on imitation cheese texture. Journal of food technology. 2009;7(2):30-33.

37. Awad RA, Salama WM, Farahat AM. Effect of lupine as cheese base substitution on technological and nutritional properties of processed cheese analogue. Acta Sci Pol Technol Aliment. 2014;13(1):55-64.

38. El-Baz AM, Ibrahim EM, Mehanna NM. Impact of using exopolysaccharides (EPS) producing cultures on improving quality of Ras cheese made from pasteurized milk. Egypt J Dairy Sci. 2011;39:127.

39. Pınar Balkır, Mustafa Metin. Physicochemical and textural properties of imitation fresh kashar cheeses prepared from casein, caseinates and soy protein. 2011.

40. Silva RCSN, Minim VPR, Simiqueli AA, et al. Optimized Descriptive Profile: a rapid methodology for sensory description. Food Quality and Preference. 2012;24(1):190-200. 
41. Montesinos-Herrero C, Cottell DC, O'Riordana ED, et al. Partial replacement of fat by functional fibre in imitation cheese: effects on rheology and microstructure. International Dairy Journal. 2006;16(8):910-919.
42. Trivedi D, Bennett RJ, Hemar Y, et al. Effect of different starches on rheological and microstructural properties of (II) commercial processed cheese. International Journal of Food Science \& Technology. 2008;43(12):2197-2203. 